Institute of $\mathbf{F}_{\text {ood and }} \mathbf{A}_{\text {gricultural }} \mathbf{S}_{\text {ciences }}$

\title{
A Low Input Sustainable Fresh Market Tomato Production System 1
}

J.R. Rich, F.M. Rhoads, S.M. Olson, and D.O. Chellemi²

\section{Introduction}

Fresh market tomato is an important vegetable crop in Florida. During the 1999-2000 season, the crop was grown on over 41,000 acres and was valued at over 418 million dollars. The production system, almost universally practiced by growers in Florida, is an intensively managed raised-bed system which includes soil fumigation, polyethylene mulch, drip or seepage irrigation, and stakes. This system produces yields that can exceed 20 tons/acre and has been widely used for over 30 years. Fumigation with a mixture of methyl bromide and chloropicrin has been a critical component of this production system and is relied upon for controlling soilborne diseases, nematodes, and weeds. However, methyl bromide is scheduled for total phase out in the United States in January, 2005 due to its ozone depletion potential.

With the impending loss of methyl bromide from Florida vegetable production systems, intensive efforts have been made by growers and scientists to develop methyl bromide alternatives, mainly in the form of soil-applied fumigants. Data from a series of tests conducted statewide have identified mixtures of 1,3-dichloropropene (Telone) and chloropicrin as the most likely alternatives to methyl bromide for nematode and disease management. Limitations in soilborne pest control with various alternatives, however, have included poor weed control and less than optimal nematode management for second crops.

An effective yet much overlooked soil and pest management practice in tomato production systems has been the rotation with sod-based production systems. This practice predates the use of methyl bromide by many years. For example, watermelon growers traditionally sought bahiagrass sod fields which have lower levels of weeds, Fusarium wilt, and root-knot nematodes. In fact, this production system is still widely used in many southeastern production areas. Sod-based production systems with grasses such as bahiagrass not only reduce soil-borne pest and weed problems but are also known to provide nutrient recycling, improved soil tilth, organic matter, and increased water holding capacities.

1. This document is ENY-678, one of a series of the Department of Entomology and Nematology, Florida Cooperative Extension Service, Institute of Food and Agricultural Sciences, University of Florida, Publication Date: February 2003. Please visit the EDIS Web site at http://edis.ifas.ufl.edu.

2. Jim Rich, professor, North Florida REC, Entomology and Nematology Department, Fred Rhoads, professor, North Florida REC, Soil and Water Science Department, Steve Olson, professor, North Florida REC, Horticultural Sciences Department, Cooperative Extension Service, Institute of Food and Agricultural Sciences, University of Florida, Gainesville, 32611; and Dan Chellemi, professor, USDA ARS, Fort Pierce, FL 34945.

The Institute of Food and Agricultural Sciences is an equal opportunity/affirmative action employer authorized to provide research, educational information and other services only to individuals and institutions that function without regard to race, color, sex, age, handicap, or national origin. For information on obtaining other extension publications, contact your county Cooperative Extension Service office. Florida Cooperative Extension Service/Institute of Food and Agricultural Sciences/University of Florida/Christine Taylor Waddill, Dean. 
Plant resistance is another pest management practice that can be used in pest management systems. During the development of the raised-bed production system, availability of plant disease resistance in tomato to nematode and soilborne fungi was limited. However in subsequent years, both the range of resistance and incorporation of resistances into highly productive tomato varieties have increased dramatically. For example, a number of stake tomato varieties available in Florida have resistance to Verticillium and Fusarium wilt (races 1, 2, 3), and root-knot nematodes. Due to pathogen adaptability, plant resistance is seldom recommended as a single control practice, rather in an integrated management system consisting of rotation or chemicals.

With the horticultural improvements in disease resistance tomatoes and the well-known record of sod-based systems, combinations of these two practices could prove adequate without use of fumigation in most production scenarios. This is particularly relevant with todays improved scouting and prediction methods. The utilization and testing of sod-based systems plus disease resistance in tomato, however, has been precluded by dependence on methyl bromide. Thus, little work has been conducted to determine either the merit or limitations of these two practices as replacements for methyl bromide. In the very least, these pest management practices could augment chemical alternatives to methyl bromide.

\section{A Strip Tillage System}

Five field tests were conducted on well established bahiagrass at the North Florida Research and Education Center, Quincy. Strip tillage was used in the bahaiagrass sod and tomatoes subsequently transplanted into the strips. Only limited plastic mulch was applied, and no fumigation was used in these tests. The main factors explored were: 1) sod management with herbicides and mechanical means; 2) strip tillage widths, 3) fertilizer rates; and 4) nematode and disease management. Additionally, a large scale farmer field evaluation, including economic analyses, was also conducted after initial trials were completed. Results from these trials are presented as production guidelines.
A. Land Preparation - Four to six feet wide row spacings can be used since no bed is formed. In fact, closer row spacings provided greatest yields. Spray strips at least 24 inches wide with glyphosate or other suitable herbicides two months before transplanting to kill the bahiagrass. Till the sprayed area after death of the bahiagrass. This may need to be repeated several times over 2-3 weeks to obtain a good seedbed.

B. Fertilization - Earlier in the field tests, it was found that bahiagrass was a competitor with the tomatoes for fertilizer and water. However, with methods described above, competition is limited and fertilizer management is similar to that of convention systems. Phosphorus and potassium should be applied according to soil test results and incorporated in the strips prior to transplanting. Dolmite should be applied in the strips at $1500 \mathrm{lb}$ actual/acre and mixed in the soil to supply magnesium and reduce blossom end rot. Nitrogen, at the normal $180 \mathrm{lb}$ actual/acre rate, is recommended using $1 / 3$ at transplanting, $1 / 3$ at three weeks after transplanting, and 1/3 at 6 weeks after transplanting. Nitrogen and potassium should be applied through the drip system to minimize leaching and competitive uptake by the bahiagrass.

C. Weed Management - The bahiagrass pasture chosen should be a solid stand at least 3 years old and have little weed growth. For weed suppression, incorporate a preplant herbicide such as Tilliam prior to transplanting. Under these conditions, weed management should be minimal with the exception of managing the bahiagrass growth in and between rows. To do so, mow the bahiagrass regularly and use the herbicide Poast at low rates several times after transplanting to stunt growth of the bahiagrass.

D. Disease Management - The use of tomato cultivars with multiple nematode and disease resistances is very important in both the conventional and the strip till system. This is particularly true for nematode resistance in the strip till system since some weedy spots in the bahiagrass may contain pockets of root-knot nematodes. Additionally, tomato spotted wilt levels have been found to be higher in strip till tomato production, thus use of cultivar resistance to TSWV is important. However, cultivars with TSWV resistance have only recently been 
developed and appropriate horticultural properties must be considered.

E. Other Practices - Other tomato production practices in the strip-till system are similar to those used in the raised-bed system. Normal pesticide application schedules are maintained, and tomato plants are staked. The amount of irrigation may need to be increased since plastic mulch is not present to reduce evaporation. Black mulch application may be made in the strip-till system for soil warming and weed management. However, equipment will need to be modified or built for applying the mulch.

\section{Advantages}

The strip till tomato production system offers many advantages compared to the conventional production system. The conventional raised-bed plastic mulch system creates conditions that favor the outbreak of many plant pests. Windblown soil created by bare row middles leads to plant injury, increasing foliar diseases. Rain splash dispersal of plant pathogens is increased on bare soil, and populations of key insect pests are increased. Benefits of strip tillage into bahiagrass include reductions in production costs associated with land preparation, no fumigant and application costs, and reduced erosion due to storm water runoff. Sod-based rotation minimizes the increase of soil-borne pests and pesticide residue in the soil and reduces the effect of soil compaction due to repeated movement of heavy machinery over the same area. Our limited but sound economic data show that grower profits can be increased due to fewer inputs (Table 1).

\section{Conclusion}

Over six million acres of bahiagrass are planted in Florida. This represents a largely untapped resource for Florida tomato growers and indeed other vegetable growers as well. The present strip till system will allow for good tomato production and a quick return to grazing since the bahiagrss is not destroyed as in the conventional system. In fact, only two to three months of growth after final tomato harvest is required before pastures can be utilized.

More research and farmer experience is needed to improve tomato production in the strip tillage system. However, the system offers the potential for tomato production that is more environmentally sound and has the potential to help the industry remain competitive.

\section{References}

Chellemi, D. O., F. M. Rhoads, S. M. Olson, J. R. Rich, D. Murray, G. Murray, and D. M. Sylvia. 1999. An alternative, low input production system for fresh market tomato. American Journal of Alternative Agriculture 14:59-68.

Rhoads, F. M., S. M. Olson, J. R. Rich, and D. O. Chellemi. 1998. Strip-till tomato in bahiagrass: Management of fertility and grass in middles. Florida Agricultural Conference and Trade Show Proceedings pp. 38-41.

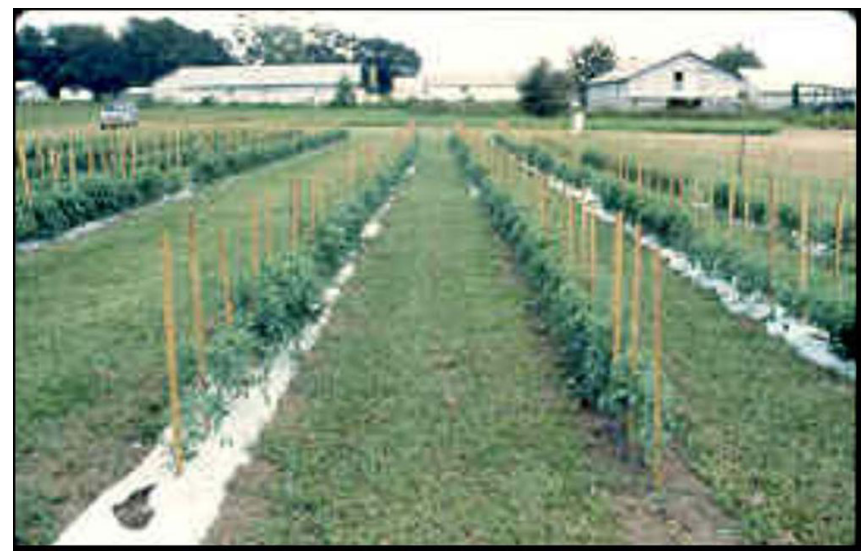

Figure 1. An initial trial with strip till tomatoes, with and without plastic mulch.

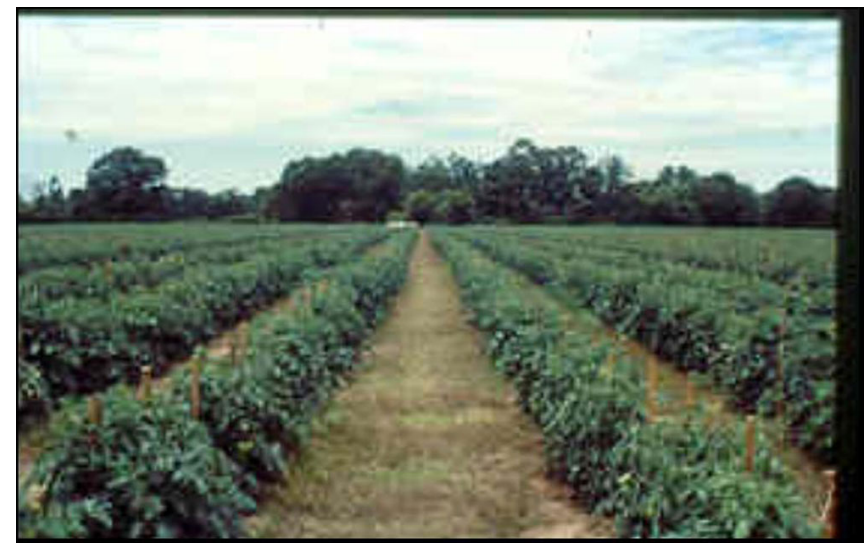

Figure 2. A field scale demonstration trial in a farmer's field. 
Table 1. Fresh market tomato production costs and economic returns per acre from a farmer field validation test of the strip till production system in northwest Florida. ${ }^{1}$

\begin{tabular}{||l|c|c||}
\hline \multicolumn{1}{|c|}{ Cost and yield } & Strip Till & Conventional \\
\hline Land Rent & $\$ 300$ & $\$ 300$ \\
\hline Equipment & $\$ 400$ & $\$ 400$ \\
\hline Production inputs & $\$ 2000$ & $\$ 2800$ \\
\hline Harvest costs & $\$ 3500$ & $\$ 4100$ \\
\hline Clean-up & $\$ 150$ & $\$ 300$ \\
\hline Yield (lbs./acre) & 32,065 & 37,854 \\
\hline Yield (No. boxes) ${ }^{2}$ & 1283 & 1515 \\
\hline Ave. market price/box & 5.90 & $\$ 5.90$ \\
\hline Net return & $\$ 1220$ & $\$ 1039$ \\
\hline${ }^{1}$ Side by side comparison of still till and conventional tomato production systems. \\
${ }^{2}$ Boxes weighed 25 lbs. each. & & \\
\hline \hline
\end{tabular}

